\title{
THE EFFECT OF MATERIALS ON THE RELIABILITY OF REINFORCED CONCRETE BEAMS IN NORMAL AND INTENSE CORROSIONS
}

\author{
WPŁYW STOSOWANYCH MATERIAŁÓW NA NIEZAWODNOŚĆ BELEK \\ ŻELBETOWYCH W WARUNKACH NORMALNEJ I SILNEJ KOROZJI
}

\begin{abstract}
Concrete structures are exposed to a variety of damages during their lifetime each of which could contribute to reducing their service life and load bearing capacity. Since most of parameters have special role in estimating capacity of members which are not certain, probabilistic evaluating the performance of concrete structures could bring more realistic perception about analysis and design of these structures. One of the most frequent probable damages is corrosion. The main focus of this study is placed on reliability assessment of flexural behavior of a reinforced concrete beam experienced pitting corrosion via Monte Carlo simulation. In addition, the effects of time to corrosion initiation, steel rebar diameter, yielding stress of rebars, strength class of cement, aggregate type and compressive strength of concrete, are included both in intense and normal pitting corrosion. The results clearly illustrate that occurrence of intense corrosion in concrete with low compressive strength, which used of higher strength class of cement and crushed stone aggregate, and less initial time for corrosion will lead to considerable reduction in service life even in some cases nearly half.
\end{abstract}

Keywords: failure probability, Monte Carlo simulation, pitting corrosion, flexural capacity, RC beams.

\begin{abstract}
W trakcie cyklu życia, konstrukcje betonowe sa narażone na wiele uszkodzeń, z których każde może przyczyniać się do skrócenia ich żywotności i nośności. Ponieważ większość parametrów odgrywających szczególna rolę w szacowaniu nośności elementów cechuje niepewność, ocena probabilistyczna charakterystyk struktur betonowych może dawać bardziej realistyczny obraz analizy i projektowania tych struktur. Jednym z najczęściej występujących uszkodzeń struktur żelbetowych jest korozja. Głównym celem niniejszego badania byta ocena niezawodności zachowania zginanej belki żelbetowej doświadczalnie poddanej korozji wżerowej poprzez symulację Monte Carlo. Ponadto, badano oddziatywanie czasu inkubacji korozji, średnicy stalowych prętów zbrojeniowych, granicy plastyczności tych prętów, klasy wytrzymatości cementu, rodzaju kruszywa i wytrzymałości na ściskanie betonu zarówno w warunkach silnej jak i normalnej korozji wżerowej. Wyniki jasno pokazuja, że wystapienie silnej korozji w betonie o małej wytrzymałości na ściskanie, do produkcji którego wykorzystano cement i kruszywo kamienne o wyższej klasie wytrzymatości, oraz krótszy czas inkubacji korozji prowadza do znacznego skrócenia żywotności belek, w niektórych przypadkach nawet prawie o połowe.
\end{abstract}

Stowa kluczowe: prawdopodobieństwo awarii, symulacja Monte Carlo, korozja wżerowa, nośność na zginanie, belki żelbetowe.

\section{Introduction}

Recent investigations on structures located in coastal areas with hot weather, indicates that sizable number of these structures are at stake of either sulfates or corrosive substances attack [16]. Today, most of impairments during serviceability of concrete structures are concerned to steel corrosion especially in marine structures and concrete bridges [1]. Reinforcing steel is normally passive in concrete due to high alkalinity of the concrete pore solution, however, chlorides or carbonation penetration into the concrete, destroys this inhibitive property of the concrete and leads to corrosion [38]. Two types of corrosion -general and pitting -are possible [14]. General corrosion affects on cross section of reinforcement with more or less uniform metal loss over the perimeter of reinforcing bars [28]. It also causes cracking and eventually spalling of the concrete cover and produces rust staining on the concrete surface so it can be detected quite easily during inspection of a structure [39]. Pitting or localized corrosion, in contrast to general corrosion, concentrates over small areas of reinforcement. Pitting corrosion often does not cause disruption of the concrete cover and produces little rust staining on the concrete surface and so it may be difficult to be discovered during inspection [18-19]. Despite that a numerous researches have been done about time dependent reliability of these deteriorating structures, most of them are based on uniform corrosion assumption [12, 15-16]

Stewart [34], Stewart \& Al Harthy [32] and Stewart \& Suo [35] studied the spatial effects of local corrosion in reliability of bending behavior of concrete beams. These researchers developed a Stochastic model for pitting corrosion in a simply supported beam in which Eigen value theory is applied with the intention of predicting the maximum value of corrosion depth as function of both diameter and length of steel rebar. Note that, they presumed following assumptions: i) statistical data about corrosion depth were gathered based on limited number of previous studies, ii) ductile rapture mode of steel rebar is presumed, iii) the effect of corrosion on steel material is neglected. 
Subsequently Stewart \& Al Harthy [32] elevated previous study $[34,33]$ by employing a progressive corrosion data on two rebar diameter namely 16 and 27 in order to achieve modified Eigen value for pitting corrosion. Unlike the former study, they also considered the corrosion impact on steel material. Interestingly in the present article, the same approach is recruited, will be depicted in Sec.4.Barone and Frangopol investigated the probabilistic approaches and obtained that Maintenance schedules are for life-cycle maintenance of structural systems [3]. Zhang et al. presented the time-dependent probability of chloride-induced corrosion of reinforced concrete (RC) structures in marine environments, by developing the third-moment (TM) method [41].According to Simioni [31] and Pedeferri [27], often the amount of cross-sectional reduction is intense and neglecting it in the design of RC structures can lead to serious damage.

Based on the studies conducted above, the outcome of section area reduction due to corrosion intense is not discussed; so, in the present article, a probabilistic model for flexural behavior of a beam is suggested in pursuit of reliability assessment of concrete beams with rectangular section which are subjected to pitting corrosion with two kinds of pitting scenarios (intense and normal pitting) based on the amounts of pit depths. More precisely, all the possible detrimental impacts of corrosion comprised of cross section reduction, decrease in yield stress and so on, are considered in the process. Based on suggested probabilistic model, reliability assessment of a reinforced concrete beam will be evaluated via employing Monte Carlo simulation. Finally, according to the results, the role of different parameters in serviceability of beam will be reported.

\section{Deterioration process}

After initial corrosion and during of corrosion propagation, load bearing capacity of RC members decreased [28].

\subsection{Corrosion initiation}

The time to corrosion initiation will be calculated regard to second diffusion law in 1 dimensional in semi-finite solid body (Fick's law according to Eq. (1)), shown in Eq.(2). It should be noted that diffusion in the practical process are different from that assumed with Fick's law, yet it is used normally for simulating chloride ingress in concrete, because of its accuracy $[5,2]$ :

$$
\begin{gathered}
\left(\frac{\partial f}{\partial t}=D_{c} \frac{\partial^{2} f}{\partial x^{2}}\right) \\
T_{0}=\frac{C^{2}}{4 D_{c}}\left[e r f^{-1}\left(1-\frac{C_{t h}}{C_{0}}\right)\right]^{-2}
\end{gathered}
$$

where "C" is the cover (cm), "erf" indicate the error function, $C_{t h}$ and $C_{0}$ is the chloride threshold and constant amount of chloride on surface $\left(\mathrm{kg} / \mathrm{m}^{3}\right)$ respectively and $D_{c}$ is indication of chloride diffusion coefficient $\left(\mathrm{cm}^{2} / \mathrm{s}\right)$, which directly correlated with Water-cement ratio, environmental condition like temperature and humidity level. It will be calculated as follow $[4,6]$ :

$$
D_{c}=\left[1.249-5.051 w c+8.941 w c^{2}\right] \times 10^{-8}
$$

According to the building research establishment of Iran [7], the relationship between the water to cement ratio (W/C), the type of aggregate in the concrete and strength class of cement with compressive strength of concrete are obtained by the following relationships.
For crushed aggregate and strength class of cement(C 525):

$$
F_{c}(M P a)=573.91(w / c)^{3}-984.34(w / c)^{2}+435.71(w / c)+4.4767(4-a)
$$

For round aggregate and strength class of cement (R 525):

$$
F_{c}(M P a)=545.45(w / c)^{3}-894.81(w / c)^{2}+369.48(w / c)+13.818
$$

For crushed aggregate and strength class of cement (C425):

$$
F_{c}(M P a)=525.25(w / c)^{3}-817.75(w / c)^{2}+313.6(w / c)+22.121
$$

For round aggregate and strength class of cement (R 425):

$$
F_{c}(M P a)=707.07(w / c)^{3}-1087.4(w / c)^{2}+450.57(w / c)+5.6061(4-\mathrm{d})
$$

\subsection{Corrosion propagation}

Quantitative definition of corrosion propagation is provided primarily in the form of corrosion rate which is offered as amount of steel loss per unit time and unit area. Most of current non-destructive techniques detects the corrosion whereby electromechanical measurement of current rate $\left(i_{c o r r}\right)$.Stewart et al, developed an analytical model for estimating the corrosion which is dependent upon parameters like quality of concrete and rebar cover [17, 39]:

$$
\left(i_{\text {corr }}(T)=0.85 i_{\text {corr }}(1) \cdot T^{0.29}\right)
$$

In which "T" indicates how long corrosion have initiated ( $T=t-T_{0}$ ), T0 shows the initiation time of corrosion and " $\mathrm{t}$ " is the structure life (year). This equation is viable to be used for cities located in Asia, Europe, America and Australia [39, 40]. One major drawback of this equation is affiliated with corrosion with short periods of structure life. In other words, if " $\mathrm{T}$ " is small $\left(t \approx T_{0} \rightarrow T \approx 0\right)$, corrosion rate tends to reach infinity. In this respect, modified mentioned equation as below [40]:

$$
i_{\text {corr }}(T)=\left\{\begin{array}{cc}
i_{\text {corr }}(1) & 0 \leq T \leq 1 \text { year } \\
0.85 i_{\text {corr }}(1) \cdot T^{-0.29} & T>1 \text { year }
\end{array}\right.
$$

In which $i_{\text {corr }}(1)$ is the one year corrosion rate at the start of corrosion initiation $\left(\mu \mathrm{A} / \mathrm{cm}^{2}\right)$, which is suggested as following equation [10]:

$$
i_{\text {corr }}(1)=\frac{37.8(1-w c)^{-1.64}}{C}
$$

In general corrosion in order to calculate corrosion rate, according to Faraday's law of electrochemical equivalence will be recruited into steel mass loss, which $i_{\text {corr }}$ the corrosion rate. $\Delta \mathrm{D}$ indicates the diameter reduction $(\mathrm{mm})$ and " $\mathrm{T}$ " illustrate the number of years [8]:

$$
\Delta D(T)=0.0232 i_{\text {corr }} * T
$$




$$
A_{S}(T)=n \frac{\pi\left[D_{0}-\Delta D(T)\right]^{2}}{4} \geq 0
$$

If corrosion current density is assumed to be identical for " $n$ " steel rebars with diameter $\mathrm{D}_{0}$, the cross section area of rebars could be resulted according to Eq.(9), but if corrosion is local, the cross section of the rebars should be calculated as:

$$
A_{S}(T)=n\left(\frac{\pi D_{0}^{2}}{4}-A_{P i t}\right) \geq 0
$$

where $A_{P i t}(t)$ and $A_{S}$ is the cross section area of corroded and noncorroded rebar, respectively. " $n$ " is cited as the number of rebar, and $A_{P i t}(t)$ will be seen in Fig. 1 and calculated as following equation $[38,35,21]$ :

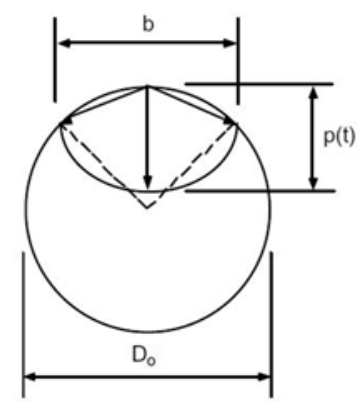

Fig. 1. Configuration of pitting corrosion in rebar [38, 41$]$

$$
A_{P i t}(T)= \begin{cases}A_{1}+A_{2} & P(T) \leq \frac{D_{0}}{\sqrt{2}} \\ A_{S}-A_{1}+A_{2} & \frac{D_{0}}{\sqrt{2}}<P(T) \leq D_{0} \\ A_{S} & P(T)>D_{0}\end{cases}
$$

where:

$$
P(T)=0.0116 . i_{\text {corr }}(T) \cdot R \cdot T
$$

$$
A_{S}=\frac{\pi \cdot D_{0}^{2}}{4}
$$

$$
A_{1}=0.5\left[\theta_{1}\left(\frac{D_{0}}{2}\right)^{2}-b\left|\frac{D_{0}}{2}-\frac{P(T)^{2}}{D_{0}}\right|\right]
$$

$$
A_{2}=0.5\left[\theta_{2} P(T)^{2}-b \frac{P(T)^{2}}{D_{0}}\right]
$$

$b=2 P(T) \sqrt{1-\left(\frac{P(T)}{D_{0}}\right)^{2}}, \theta_{1}=2 \arcsin \left(\frac{b}{D_{0}}\right), \theta_{2}=2 \arcsin \left(\frac{b}{2 P(T)}\right)$

In above equation, $P(T)$ is the maximum pit depth $(\mathrm{mm}), \mathrm{R}$ is pitting factor will calculated as the ratio of $P(T)$ to average corro- sion in a period of years $\left(R=P(T) / \mathrm{P}_{a v}\right)$. Additionally, $i_{c o r r}(T)$ is corrosion rate, which is a function of time (in term of $\left(\mu \mathrm{A} / \mathrm{cm}^{2}\right)$ ), and $\mathrm{T}$ were defined in the previous section. In fact, in case of normal corrosion with usual penetration rate of flexural capacity reduction of beam as a result of the loss of transverse cross-sectional area of rebars (according to Eqs. 12-16), Even after 100 years it is negligible and with fact of many observations of marine structures in extreme areas, is inconsistent. For this reason, in this study, to achieve a more realistic behavior of structures under severe corrosion, pitting depth in Eq. (12), was considered ten times the usual amount.

\section{Reliability assessment}

Reliability of many practical problems can be investigated through a mathematical model composed of " $R$ " related to strength of material and "S" associated with imposed load. These mathematical models are known as limit state functions indicative of an intended behavior of the structure. It is worth to mention that a damage will be induced to the structure when the imposed load are larger than structure capacity; that is, when $G=R-S$ is minus $[21,23]$ :

$$
P_{f}=\iint_{R-S<0} f_{S, R}(\mathrm{~s}, r) d s d r=P[G(U)<0]=\int_{G(U)<0} f_{X}(X) d X
$$

in which $P_{f}, G(U)$ and $f_{X}(X)$, are failure probability of structure, limit state function and joint probability density function of variables, respectively.

The major problem in reliability assessment of structures is solution of abovementioned integration. One of the suggested approximate solutions for mentioned integration is Mont Carlo simulation $[30,23]$.According to the definition counter function, failure probability can be written as [23]:

$$
\begin{aligned}
& P_{f}=\int_{G(x) \leq 0} f_{x_{1} \cdots x_{n}}\left(x_{1}, \cdots, x_{n}\right) \mathrm{dx}_{1} \cdots d x_{n} \\
& =\int_{\infty}^{\infty} \cdots \int_{-\infty}^{\infty} I[X] f_{x_{1} \cdots x_{n}}\left(x_{1}, \cdots, x_{n}\right) d x_{1} \cdots d x_{n}
\end{aligned}
$$

And finally $\mathrm{P}_{\mathrm{f}}$ can be written as follow:

$$
P_{f}=\int_{G(x) \leq 0} \cdots \int f_{x_{1} \cdots x_{n}}\left(x_{1}, \cdots, x_{n}\right) d x_{1} \cdots d x_{n} \approx \frac{1}{N} \sum_{i=1}^{N} I\left[X_{i}\right]
$$

where:

$$
I[X]= \begin{cases}0 & G(x)>0 \\ 1 & G(x) \leq 0\end{cases}
$$

\section{Probabilistic beam model for corrosion}

A probabilistic model is comprised of a variety of random variables such as load and material strength which will be analyzed via a limit state function. This model should be inclusive of both all possible uncertainties in reliability assessment and statistical parameters of the damage. Consequently, at first in this section devoted to propose the desirable limit state function suited for flexural behavior of reinforced concrete beams, at last aimed at offering felicitous statistical specifications of time to corrosion initiation formula. 


\subsection{Limit state function}

Nominal ultimate flexural strength of a concrete beam with rectangular section could be readily resulted from bending theory. By considering characteristic and equilibrium equations, nominal flexural capacity will yielded $\left(M_{n}\right)$ as it is explicit observable from the Eq.(21), there is positive correlation between area of steel rebars and flexural strength $[35,4]$ :

$$
M_{n}=A_{s}(t) f_{y}\left[d-\frac{A_{s}(t) f_{y}}{1.7 b f_{c}^{\prime}}\right]
$$

According to mention in sec 3, limit state function for flexural capacity written as follow;

$$
G(M)=M_{n}-M_{u}
$$

Where $M_{u}$ is imposed moment due to external loads and $\left(M_{n}\right)$ is nominal flexural strength of the beam. According to above equation, the probabilistic model could be developed as following equation involving both uncertainties of strength and steel deterioration:

$$
\begin{gathered}
G(M)=M E_{m} A(T) f_{y}(T)\left(d-K \frac{A_{s} \cdot f_{y}(T)}{b \cdot f_{c}}\right)-M_{u} \\
f y(T)=\left(1-\alpha \frac{A_{s}-A_{s}(T)}{A_{s}}\right) \mathrm{f}_{y}
\end{gathered}
$$

In the above limit state function, $f_{y}(T)$ is yield stress of corroded steel which is linearly correlated with un-corroded one, $\left(A_{S}-A_{S}(T)\right)$ and $\alpha$ coefficient is an experimental parameters which is normally recommended to be $0.5[35,21]$. A numerical study with full detail is available in ref. [21] which properly predicts the capacity of the structures subjected to corrosion, yet even these analysis do not consider the spatial effects of corrosion and redistribution of load among residual rebars after at least a failure. These fields of studies requires more research in future. It is instructive to note that in the limit state function mentioned in Eq.(23), uncertainties were considered in forms of $M E_{m}[35,26,23]$.

\section{Reliability assessment of corroded $\mathrm{RC}$ beam}

Limit state function mentioned in Eq.(23), is a probabilistic formulation for prediction of occurring flexural failure of a concrete beam, which also embraces independent random variables. These variables are simulated by a group of probability functions such as Normal, Lognormal and Gumbel distribution function. Note that varying properties of corrosion initiation is resulted from statistical analysis and the rest of properties are assumed based on previous studies in literature. Accordingly, the analytical model is composed of a one span concrete beam with simply supports at the ends subjected to a uniform distributed load. It has $10 \mathrm{~m}$ length, and rectangular cross-section with 0.35 width and 0.8 height. Two groups of rebar layout are considered for longitudinal reinforcing steel one of which has 9 rebars with $25.4 \mathrm{~mm}$ diameter ( $A_{s}=4560 \mathrm{~mm}^{2}$ ) and the other one possesses 3 rebars with $43 \mathrm{~mm} \operatorname{diameter}\left(A_{s}=4356 \mathrm{~mm}^{2}\right)$. Finally, as mentioned before, independent variables in limit state function will be analyzed via Monte Carlo simulation.

\subsection{Statistical properties of corrosion variables}

As it shown in Eq.(6), corrosion rate is relevant upon concrete characteristics and initiation of corrosion. Besides, according to Eq. (2), initiation time, itself, is dependent on concrete cover, chloride threshold and constant amount of surface chloride and diffusion coefficient. Similarly, diffusion properties is also at the mercy of water to cement ratio; hence, it can be concluded that initiation time of corrosion is a function of water to cement ratio, that is related to compressive strength of concrete.

In Tables 1-3 each random variables with mean and coefficient of variation and type of distribution are defined.

\subsection{Pitting factor $(R)$}

As it was mentioned earlier, unlike general corrosion, pitting corrosion aims at limited area of rebars; thus, the corroded area in pitting corrosion might be much less than corrosion resulted from $i_{c o r r}$. As a result, $i_{\text {corr }}$ should not be employed directly to evaluate the crosssectional corroded area. According to study conducted by Gonzaleset al. [16], the maximum pit depth is roughly $4-8$ times bigger than correspondent value for general one. For example, results for rebars with length of $125 \mathrm{~mm}$ and diameter of $8 \mathrm{~mm}$ are in accordance with results in Tuutti1982 [37] in which "R" for rebars with length of $150-300$ $\mathrm{mm}$ and diameter bounded below by $5 \mathrm{~mm}$ and above by $10 \mathrm{~mm}$ is reported between 4-10.

Based on Tuutti 1982 [37], there is a considerable uncertainty for parameter " $R$ ". In order to address this issue, one of the most common approaches is probabilistic modeling via eigen value theory. For this purpose, this parameter is modeled as random variable Gumbel distribution, resulted form Turnbull 1993 [36]. Note that since this approach is pervasively recruited for steel plates, pipelines and prestressed cables, which leads to acceptable results, it is reasonable to employ that here to involve uncertainty for "R".

Table 1. Statistical characteristics of effective variables in estimating the corrosion initiation

\begin{tabular}{|c|c|c|c|c||}
\hline Parameter & Mean & COV & Distribution & Reference \\
\hline Concrete cover $(\mathrm{mm})$ & 50 & 0.12 & Normal & Darmawan et al.(2010) [11] \\
\hline$c_{0}\left(\frac{\mathrm{kg}}{\mathrm{m}^{3}}\right)$ & 3.05 & 0.74 & Normal & Stewart (2004) [34] \\
\hline$c_{t h}\left(\frac{\mathrm{kg}}{\mathrm{m}^{3}}\right)$ & 0.9 & 0.2 & Log-normal & Stewart (2004) [34] \\
\hline$D_{c}\left(\frac{\mathrm{mm}^{2}}{\text { year }}\right)$ (High quality) & 14 & 0.75 & Log-normal & Nogueira \&, Leonel (2013) [22, 29] \\
\hline$D_{c}\left(\frac{\mathrm{mm}^{2}}{\text { year }}\right)$ (Low quality) & 163 & 0.75 & Log-normal & Nogueira \&, Leonel (2013) [22, 29] \\
\hline
\end{tabular}

Table 2. Statistical characteristics of uncertainty variables in model

\begin{tabular}{||c|c|c|c|c||}
\hline Parameter & Distribution & COV & Mean & Reference \\
\hline$M E_{m}$ (flexural model uncertainty) & Normal & 0.120 & 1.10 & Nowak et al(2005) [24] \\
\hline $\mathrm{K}$ & Normal & 0.05 & 0.59 & Stewart (2009) [35] \\
\hline$\alpha$ & Log-normal & 0.12 & 0.5 & Stewart (2004) [34] \\
\hline Parameter of pitting corrosion (R) & Gumbel & 0.22 & 5.65 & Stewart (2004) [34] \\
\hline
\end{tabular}


Table 3. Statistical characteristics of mechanical features of materials, load and resistance

\begin{tabular}{|c|c|c|c|c||}
\hline \hline Parameter & Mean & COV & Distribution & Reference \\
\hline $\begin{array}{c}f_{c} \text { concrete compressive } \\
\text { strength (MPa) }\end{array}$ & 27.6 & 0.18 & Log-normal & Mirza et al.(1979) [20] \\
\hline$f_{y}$ steel strength (MPa) & 414 & 0.10 & Log-normal & Mirza et al (1979)[20] \\
\hline Dead load( $\left(\frac{K N}{m}\right)$ & $1.05 G_{n}$ & 0.10 & normal & $\begin{array}{c}\text { Ellingwood et al.(1980) } \\
{[13]}\end{array}$ \\
\hline $\begin{array}{c}\text { Live load }\left(\frac{K N}{m}\right) \\
\mathrm{d}(\text { effective depth of cross } \\
\text { section) }(\mathrm{cm})\end{array}$ & $0.3 Q_{n}$ & 0.6 & gamma & $\begin{array}{c}\text { Chalk and Corotis (1980) } \\
{[9]}\end{array}$ \\
\hline $\begin{array}{c}\text { Concrete cover }(\mathrm{cm}) \\
\text { nominal }\end{array}$ & 0.02 & Normal & $\begin{array}{c}\text { Ostlund(1991),Lu et al. } \\
\text { (1994)[25] }\end{array}$ \\
\hline \hline
\end{tabular}

\subsection{Pitting factor via Gumbel distribution}

The following equation is used to compute $\mathrm{R}$ as a random variable modeled by the Gumbel distribution:

$$
F(R)=\exp \left\{-\exp \left[-\frac{(R-\mu)}{\alpha}\right]\right\}
$$

Where $\mu$ and $\alpha$ are Gumbel distribution parameters. According to Stewart 2004 [34], R parameter varies from 4 to 8 with assumption for rebar with $8 \mathrm{~mm}$ diameter and $125 \mathrm{~mm}$ length (between of $5 \%$ to $95 \%$ in Gumbel distribution).Then, mean value and C.O.V are 5.65 and 0.22 , respectively, which is related to $\mu_{0}=5.08$ and $\alpha_{0}=1.02$. In order to compute Gumbel distribution parameters for other rebars with different diameter, ensuing equation is suggested by Gonzales et al. [16].

$$
\alpha=\alpha_{0} \quad \mu=\mu_{0}+\frac{1}{\alpha_{0}} \ln \left(\frac{A}{A_{0}}\right)
$$

Where " $\mathrm{A}$ " is lateral area of the rebar and $\mathrm{A}_{0}$ is lateral area of rebar with $8 \mathrm{~mm}$ diameter and $125 \mathrm{~mm}$ length. There are also evidences indicating that pitting factor might decrease over the time [6].Thus, statistics reported for pit depth ought to be used conservatively.

stricted by less than 0.2 rebar diameter. In this regard, two modeling approach will be recruited.

The concrete beam which mentioned in previous section, is reliability assessed with $3 \mathrm{e} 5$ and $3 \mathrm{e} 7$ simulations of Monte Carlo for intense and normal pitting corrosion with two layout of reinforcing steels that defined in sec 5. In each analysis, one of the random variables playing role in flexural capacity of beam is considered with the intention of scrutinizing the correspondent changes.

\subsection{Effect of aggregate type and strength class of cement}

In this section, the correlation between strength class of cement and failure probability will be discussed. Figs. 3 and 4 Portrays the effect aggregate type $(\mathrm{R}=$ Round aggregate and $\mathrm{C}=$ Crushed aggregate) and strength class of

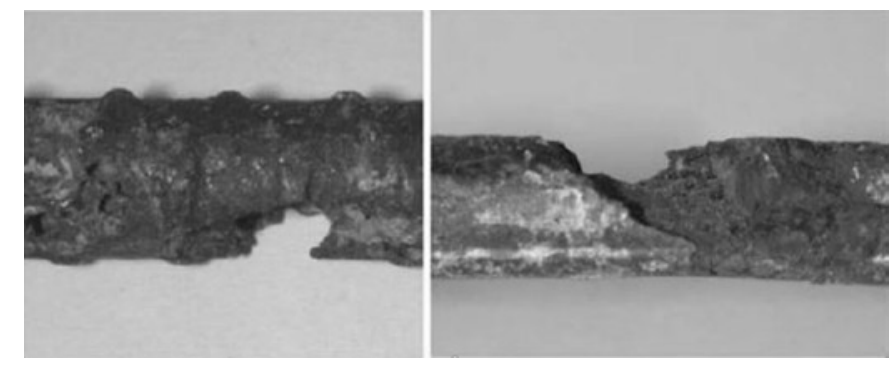

Fig. 2. The effect of intense pitting corrosion on rebar [27]

cement $\left(425 \mathrm{~kg} / \mathrm{cm}^{2}\right.$ and $\left.525 \mathrm{~kg} / \mathrm{cm}^{2}\right)$ for two layouts of longitudinal rebars.

According to the presented formula in relationship 4, for fixed compressive strength $f_{c}=27.6 \mathrm{MPa}$, for each strength class of cement and the applied aggregate, it is possible to determine the ratio of water to cement to achieve the resistance of interest. Also, according to relationships 6 and 7, after determining the corrosion rate as decreased armature area based on 11-16, it will be possible to obtain decreased flexural capacity of RC beams. By comparing the diagrams of the following charts, it will be possible to observe the effects of various strength class of cement as well as the effect of aggregate shape on the failure caused by corrosion.

\section{Analysis Results}

In general and base on mentioned equations, mostly corrosion occurrence in normal pitting corrosion, but sometimes pitting depth is very higher than equation. As it can be observed in Fig.2, pitting corrosion due to intensity of chloride concentration results to a high amount of pit depth. In practice, however, this depends on such parameters like how long and to what extent rebars have been subjected to corrosion. So as to consider this uncertainty in the simulation, corrosion parameters except pitting depth will be defined same for both intense and normal corrosion. For the first case, random variables of $\mathrm{P}(\mathrm{T})$ for calculating $A_{\text {pit }}$ in Eq.(12), considered about 10 times of normal corrosion that corrosion could progress as much as possible. Accordingly intense corrosion will be defined in Matlab Software leading to the fact that corrosion depth could be extended nearly up to rebar diameter. But for the latter case, normal pitting, Eqs.(11) to (16) will be considered for corrosion parameters, that corrosion would be re-

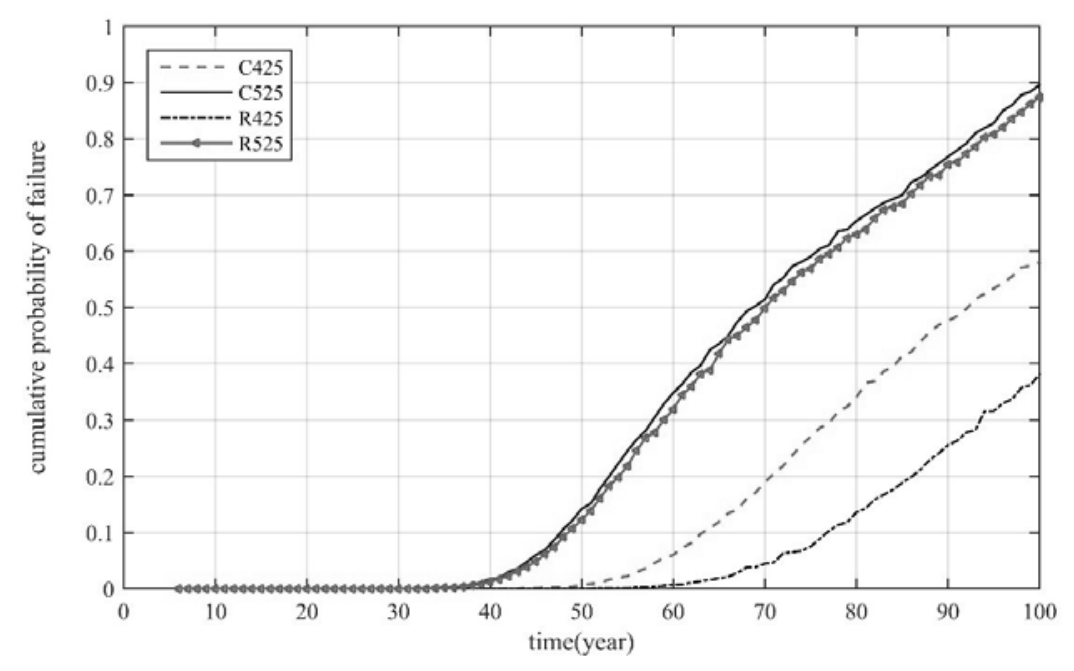

Fig. 3. Beam with rebars diameter of $25.4 \mathrm{~mm}$ with different cement strength class and aggregate type 


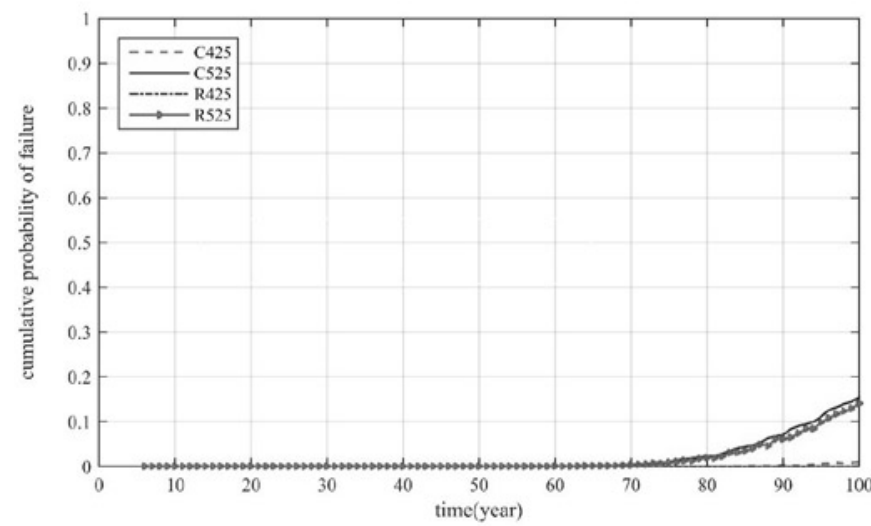

Fig. 4. Beam with rebars diameter of $43 \mathrm{~mm}$ with cement strength class and aggregate type

Despite of expectations in mix design, in case that round shaped aggregate isused for concrete mixture, the concrete beam is less probable to fail during its lifetime. In other words, usage of round shaped gravel will postpone the failure time. It is worth to mention that this delay is more considerable when it comes to concrete with smaller strength class of cement. For example, for $\mathrm{C} 425$, postponement is around 10 years whereas for C525 is nearly one year.

It is worth mentioning that regarding relationship (4) (f'c-wc), for a constant compressive strength of concrete as the strength class of cement is higher, higher water to cement ratio will be obtained. As a result, as expected, with increased ratio of water to cement (in fixed resistance), the conditions for the formation of corrosion will be prepared and the failure probability increases. That is why, according to Figs. 3 and 4, when we use cement with higher strength class, the failure probability increases.

Of course, the use of various cement strength class can implement two reverse effects on the failure probability of concrete beam; in fixed water to cement ratio, if cement with higher strength class is used, higher compressive strength of concrete will be obtained and the failure probability decreases. But in fixed compressive strength of concrete, in the case of using higher resistance, the water to cement ratio increases and the failure probability of concrete beam will be more likely.

\subsection{Effect of compressive strength of concrete}

The focus of this section is placed on evaluating the role of compressive strength of concrete in reliability assessment of the beams. Figs. 5 and 6 outlines the failure probability of the two mentioned beams with two rebars layout and different compressive strengths.

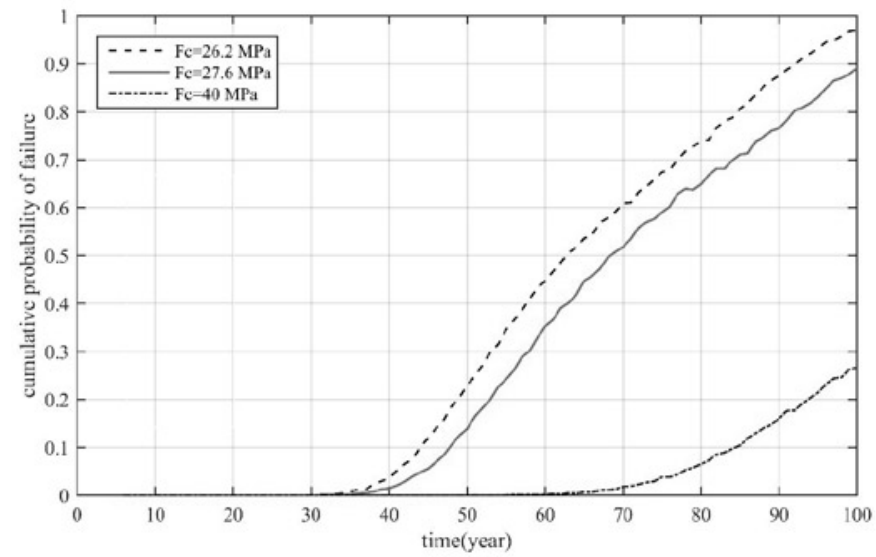

Fig. 5. Beam with rebars diameter of $25.4 \mathrm{~mm}$ with different compressive strength of concrete

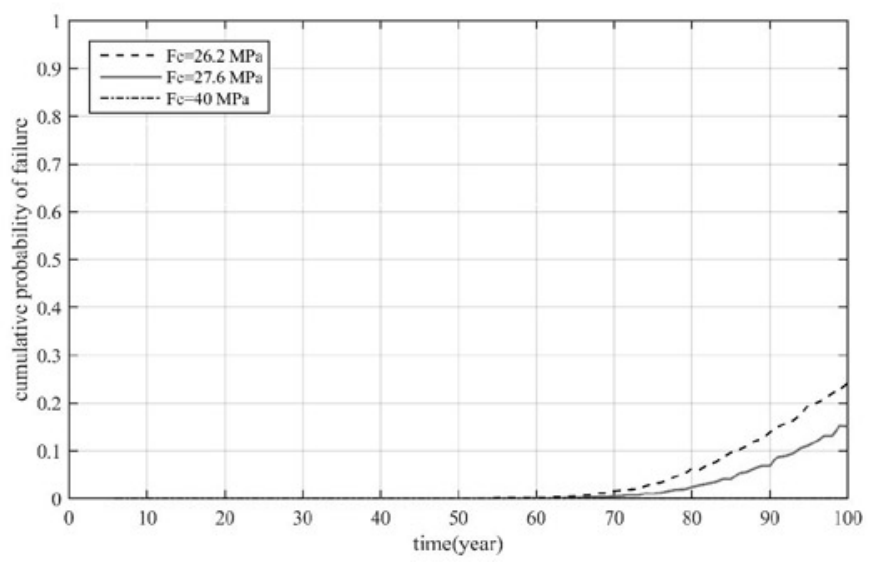

Fig. 6. Beam with rebars diameter of $43 \mathrm{~mm}$ anddifferent compressive strength of concrete

As it is observable in both figures, as the compressive strength grow, concrete beams are more resistant to corrosion which itself will lead to declining the failure probability.

\subsection{Effect of yield stress of steel rebars}

As the fourth factor that evaluated, the yield stress of reinforcing steel performing a role in reliability assessment of the concrete beams and is investigated here in this section. The effect of yield stress of rebars are presented in Figs. 7 and 8 in which are for beams reinforced with $25.4 \mathrm{~mm}$ and $43 \mathrm{~mm}$ diameter, respectively. As it is obvious in both figures, augment in yield stress will make structure

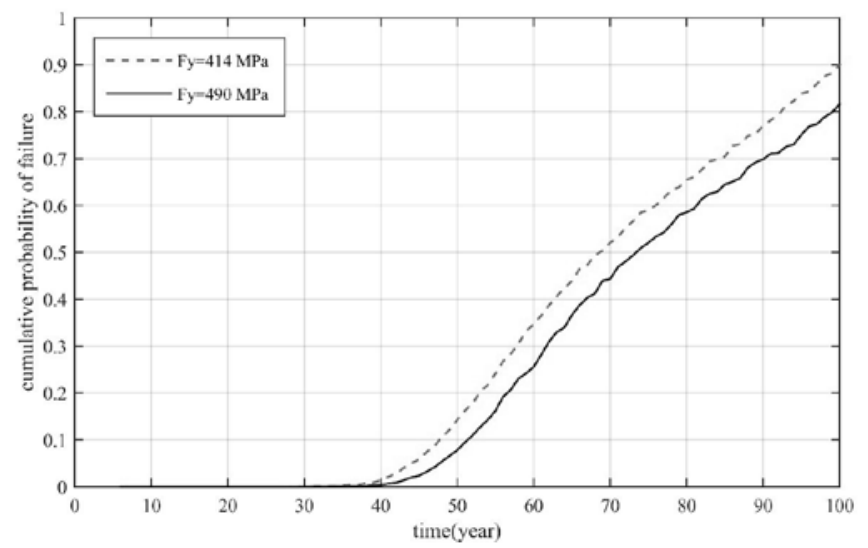

Fig. 7. Beam with rebars diameter of $25.4 \mathrm{~mm}$ and different yield stress

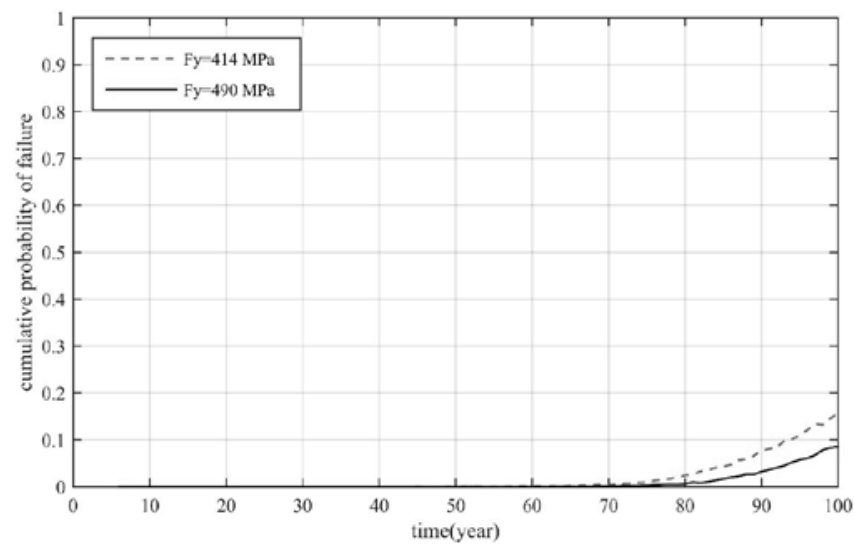

Fig. 8. Beam with rebars diameter of $43 \mathrm{~mm}$ and different yield stress 
more immune to corrosion, but it should be noted that this change is relatively low.

\subsection{Effect of diameter of steel rebars}

The last but not the least parameter played undeniable role in reliability assessment of the concrete beams is pertinent to arranging steel through out the cross section. More particularly, if " $\mathrm{A}_{\mathrm{s}}$ " $\mathrm{cm}^{2}$ is required to reinforce the section, how many and what diameters are needed. The two following figure will enlighten the role of rebar diameter for identical area of steel. In two beams with the identical physical and mechanical properties, if the diameter of longitudinal rebar is $43 \mathrm{~mm}$, probability of failure is zero for the first 40 years henceforth it soars up till the $100^{\text {th }}$ year when the probability will see $70 \%$. However, if longitudinal rebar has the diameter of $25.4 \mathrm{~mm}$, the same pattern happen for the first twenty years, the failure probability is zero, but it will experience an ascending trend after $20^{\text {th }}$ years till the $66^{\text {th }}$ year when the probability is $100 \%$.

The main reason that rebar with lower diameter after corrosion (assuming similar corrosion initiation time and ignoring cover changes in this parameter) has higher failure probability is that the corrosion penetration depth is similar for both rebar diameters. Therefore, the ratio of decreased area to the initial area and as a result, decreased flexural resistance percentage will increase in rebars with lower diameter. This issue, along with fixed load, leads to higher failure probability.

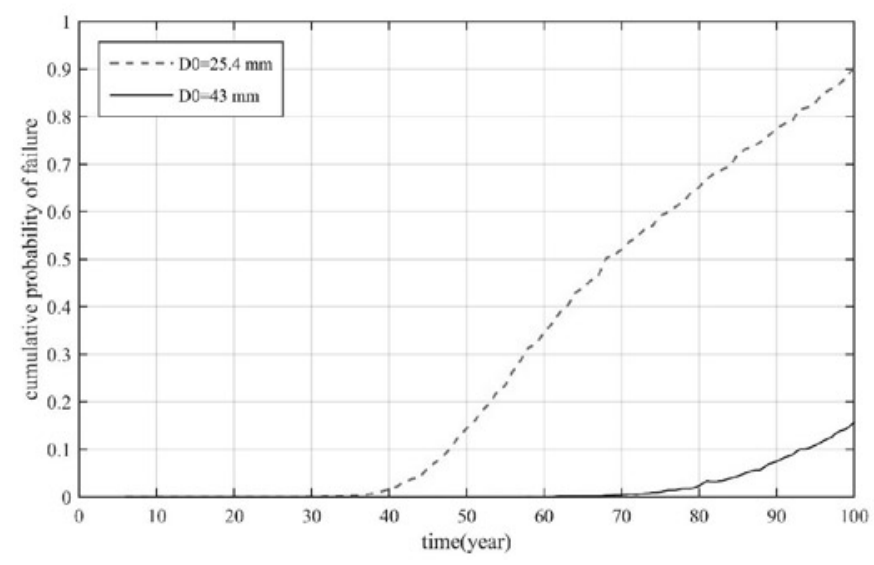

Fig. 9. Beam with different diameter at the same cross-sectional area

It should be note that in the presented diagram in Fig.9, the effects of increased diameter in decreasing cover on rebar have been ignored. Furthermore, in these diagrams, the effects of $\mathrm{R}$ variation in rebars with more diameter have been ignored. It should be noted that according to concrete quality and cover, the time difference for the corrosion initiation for rebars with different diameters changes. It is obvious that when the corrosion initiation for both rebars is almost similar, the results of Fig. 9 are valid. But increasing the time for the corrosion initiation based on Figs. 5 and 6 changes the results in Fig.9. Also, for higher time difference, the corrosion initiation for different rebar diameters can be reversed.

If the parameters presented in Tables $1 \& 3$ are used for concrete beam that studied in this paper, and for low and high quality concrete we used diffusion coefficients of $D_{c}=163 \mathrm{~mm}^{2} /$ year and $D_{c}=14 \mathrm{~mm}^{2} /$ year, the probability for corrosion for both rebar and concrete cover can be observed in the following chart. It is observed that for high quality concretes $\left(D_{c}=14\right)$, corrosion will not occur for 50 years. For low quality concretes $\left(D_{c}=163\right)$, the time difference for the corrosion initiation time for both rebars with diameters of $25.4 \mathrm{~mm}$ and $43 \mathrm{~mm}$ will be about 1 year as 7 and 6 years, respectively.

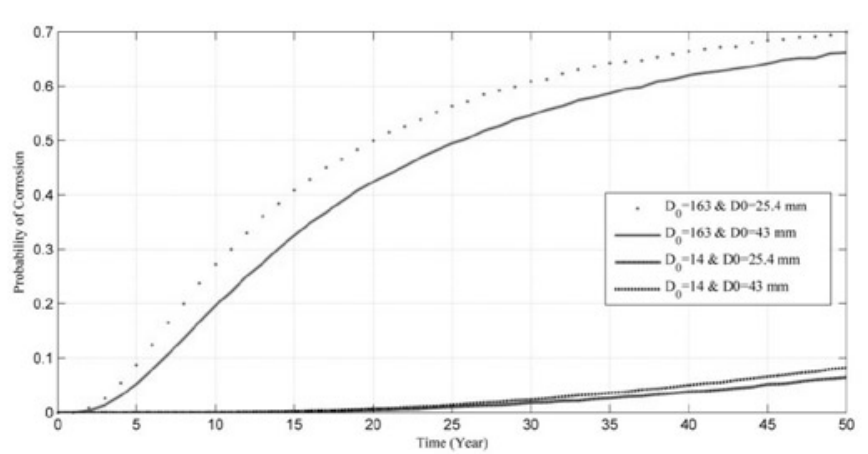

Fig. 10. The corrosion probability for rebars in both type concretes (net cover $=90-(D 0 / 2)$

In the case of using concrete with the $50 \mathrm{~mm}$ cover, as can be seen from Fig. 11, if we consider the corrosion criteria as $10 \%$, regarding concretes with high quality with 50 years lifetime, if rebars with diameters of $25.4 \mathrm{~mm}$ and $43 \mathrm{~mm}$ are used, the corrosion initiation will be 2 and 1 years, respectively.

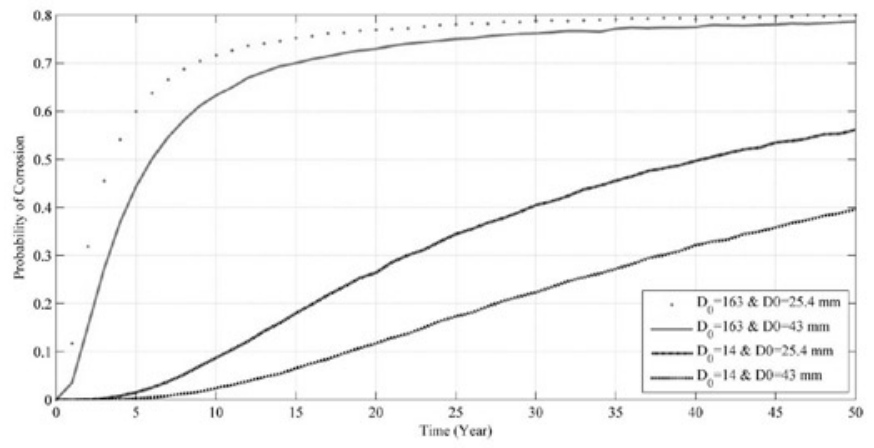

Fig. 11. The corrosion probability for rebars in both type concretes (net cover $=50-(D 0 / 2)$

According to Figs. 10 and 11, the highest time difference for the corrosion initiation for two different rebars while using high quality concrete (lower water to cement ratio and lower diffusion coefficient), with the concrete cover is lower. Therefore, in this condition, due to the occurrence of rapid corrosion in larger rebars, the damage to the structures with larger rebars will be larger.

\subsection{Effects of corrosion initiation time}

Figs. 12 and 13 are diagrams depict failure probability of the beam with different time of corrosion initiation and different rebar layout. By comparing figures, the impact of initiation time of corrosion on flexural failure probability will be illuminated. It is observed that as

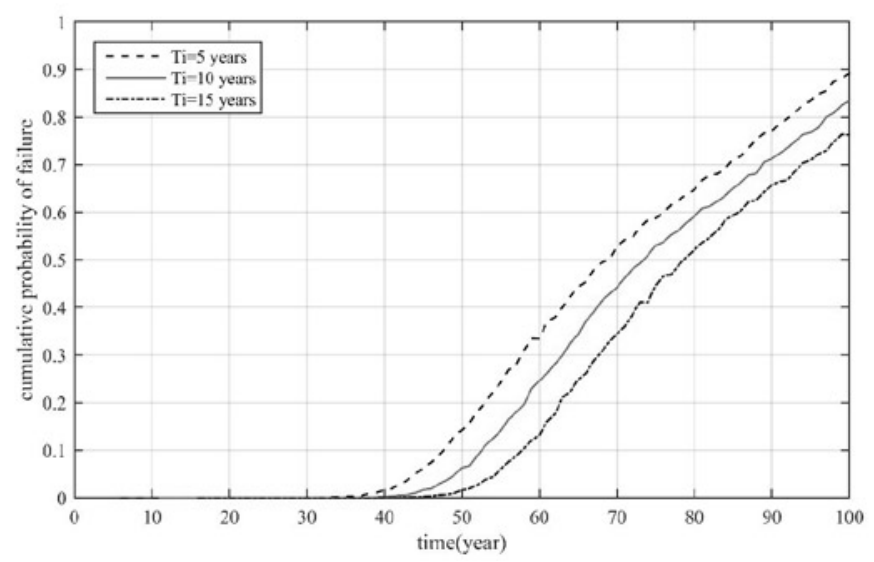

Fig. 12. Beam with rebars diameter of $25.4 \mathrm{~mm}$ at different time of corrosion initiation 


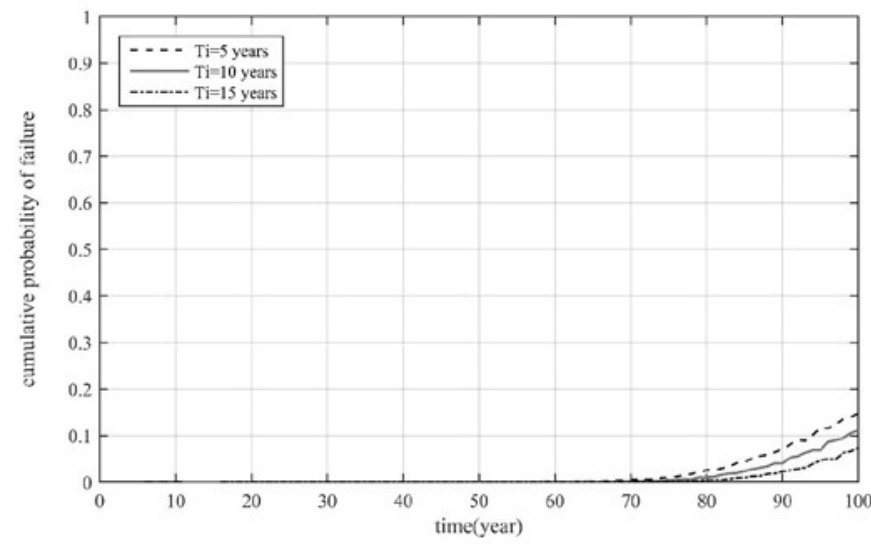

Fig. 13. Beam with rebars diameter of $43 \mathrm{~mm}$ at different time of corrosion initiation

the time of corrosion initiation is increased (lower diffusion coefficient and larger cover), the failure probability of structure is lower.

As it can be perceived in Figs. 12 and 13, as the initiation time of corrosion rises, the probability of failure decreases as expected. However, for a given service life of 100 years, it can be observed that the bigger diameter for rebars leads to the less failure probability of the beam. An illustration of this could be seen for the two beams. The samples reinforced with $25.4 \mathrm{~mm}$ rebar diameter, all fails are about 75 to $90 \%$ after 100 years while the other group of beam (with $43 \mathrm{~mm}$ rebar diameter) are remain less than 20 percent of failure probability after 100 years.

\subsection{Corrosion with normal pitting}

In this type of pitting the concrete beam mentioned in previous sections, is reliability assessed with $3 \mathrm{e} 7$ simulations of Monte Carlo. All of discussed in previous section could be generalized for the case of corrosion with normal pit with exception that in this case all the failure probability will significantly decline in comparison with intense pitting. Besides, according to Figs.14-16, the range of variation in results is inconsiderable for a period of 100 years. So it can be concluded that the whole process of corrosion with normal pit can be neglected. Main reason of in subject, is slight reduce in cross-section according to Eqs.(12) to (16) even after 100 years. That lead to almost constant flexural capacity without considerable reduction and subsequently limit state function remain positive in flexural capacity.

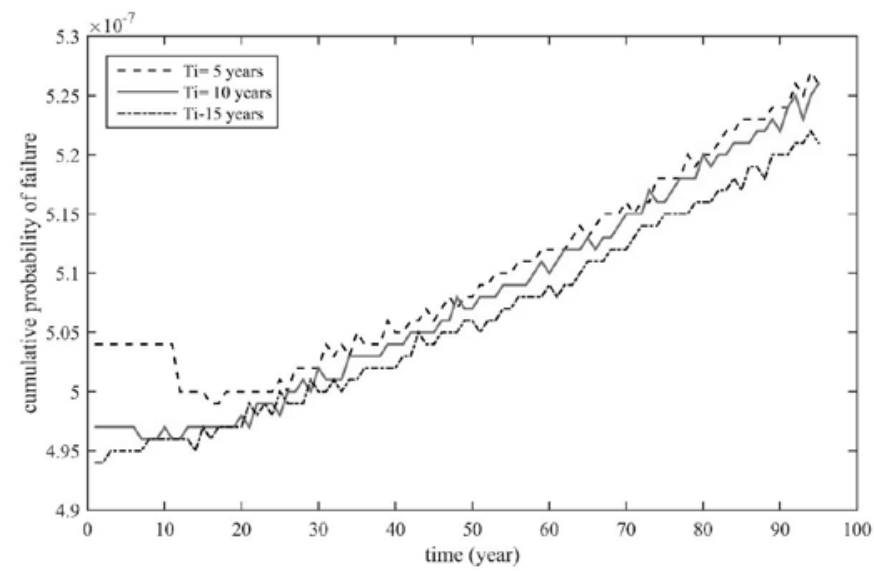

Fig. 14. Beam with rebars with a diameter of $25.4 \mathrm{~mm}$ at different corrosion beginning times

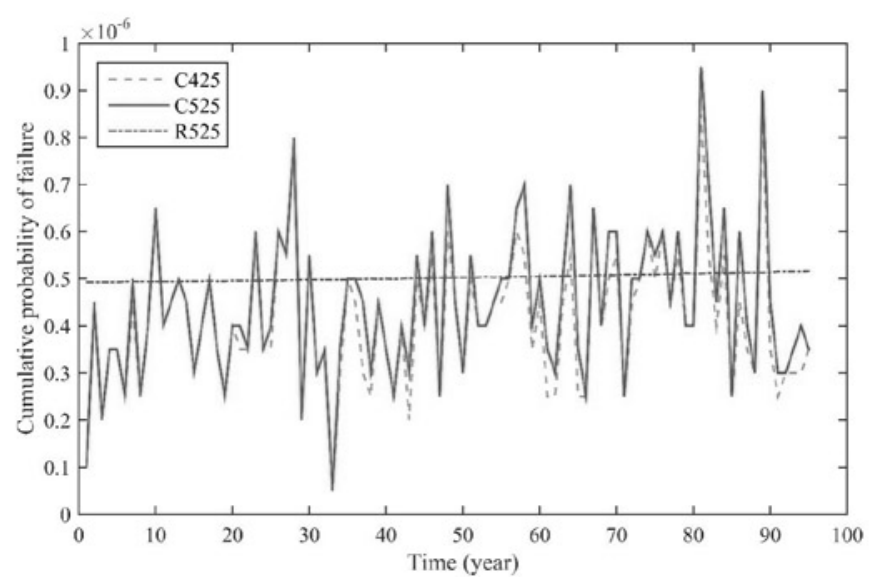

Fig. 15. Beam with rebars diameter of $43 \mathrm{~mm}$ with different aggregate and cement strength class

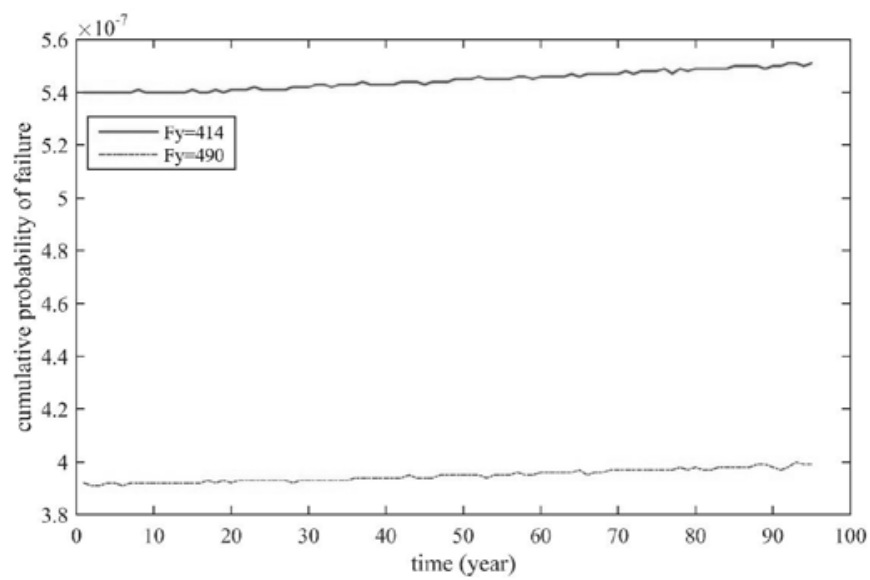

Fig. 16. Beam with rebars with a diameter of $25.4 \mathrm{~mm}$ with different beam yield stress

\section{Conclusion}

In the present study, a probabilistic model for reliability assessment of concrete beams involving various kinds of uncertainties, compressive concrete strength and steel layout, is proposed. Two structures are reliably assessed for residual life-time. Besides, the effect of aggregate type, strength class of cement, compressive strength of concrete, yield stress of rebar and bar diameter are also evaluated. According to performed reliability assessment, amount of water to cement ratio of mixture is the most important parameter for reliability of corroded RC beams. Following points could be summarized for the analysis results:

- Enhancing compressive strength of concrete as well as concrete cover will lead to making the structures more resistant to corrosion. It should be noted that increasing concrete cover is the most inexpensive and practically feasible way to protect the reinforcing steel from corrosion. For example, for the case of diffusion coefficient and $\mathrm{D}_{\mathrm{c}}=14 \mathrm{~mm}^{2} /$ year, if the cover increase $40 \mathrm{~mm}$, the failure probability might decrease between $30 \%$ $45 \%$.

- Increase of time to corrosion initiation (with less diffusion coefficient of concrete or high quality of concrete and higher concrete cover) contributes to decrease the failure probability of beams.

- According to the results, utilization of aggregate with round shaped corner will adjourn the failure of the structures. This delay in failure of structures is more considerable for concrete with less strength class of cement. 
- According to the results, failure probability of corroded beam, in case of beam with higher compressive strength, is less.

- Augmenting the yield stress of longitudinal reinforcement will slightly reduce the failure probability of concrete corroded beams.

- With assumption of equal initiation time of corrosion for rebar with different diameter (in term of effecting parameters for corrosion initiation such concrete cover and diffusion coefficient), usage of thicker reinforcement when the same area of steel, contribute to decline the failure probability of beams. But in case of high quality of concrete mix, with lower concrete cover, usage of thicker reinforcement with the same area of steel, contribute to increase the failure probability of beams.
- - It is observed that in case of local corrosion with normal pitting, the same results will be reported, but the difference is that the failure probabilities are far less than intense corrosion. In this case, since most of the time, safety factor is large, corrosion could be totally neglected as a detrimental factor.

\section{Acknowledgement}

The present study was financially supported by Committee for Scientific Research of Islamic Azad University, East Tehran Branch, Tehran, Iran (IAUET).

\section{References}

1. Ahmad S. Reinforcement corrosion in concrete structures, its monitoring and service life prediction-A review. Cement and Concrete Composite 2003; 25: 459-471, https://doi.org/10.1016/S0958-9465(02)00086-0.

2. Almusallam A A. Effect of degree of corrosion on the properties of reinforcing steel bars. Construction and Building Materials 2001; 15(8): 361-368, https://doi.org/10.1016/S0950-0618(01)00009-5.

3. Barone G, Frangopol D M. Reliability, risk and lifetime distributions as performance indicators for life-cycle maintenance of deteriorating structures. Reliability Engineering \& System Safety 2014; 123: 21-37, https://doi.org/10.1016/j.ress.2013.09.013.

4. Bastidas-Arteaga E, Bressolette P, Chateauneuf A, Sánchez-Silva M. Probabilistic lifetime assessment of RC structures under coupled corrosion-fatigue deterioration processes. Structural Safety 2009; 31(1): 84-96, https://doi.org/10.1016/j.strusafe.2008.04.001.

5. Bastidas-Arteaga E, Sánchez-Silva M, Chateauneuf A, Silva M R. Coupled reliability model of biodeterioration, chloride ingress and cracking for reinforced concrete structures. Structural Safety 2008; 30(2): 110-129, https://doi.org/10.1016/j.strusafe.2006.09.001.

6. Bhargava K, Mori Y, Ghosh A K. Time-dependent reliability of corrosion-affected RC beams-Part 1: Estimation of time-dependent strengths and associated variability. Nuclear Engineering and Design 2011; 241(5): 1371-1384, https://doi.org/10.1016/j.nucengdes.2011.01.005.

7. Building Research Establishment. Iranian Design Code for Normal Concrete Mixes. second edition 2005.

8. Bushman J B, Engineer P P. Calculation of Corrosion Rate from Corrosion Current (Faraday's Law). Bushman \& Associates Inc. 2000.

9. Chalk P L, Corotis R B. Probability model for design live loads. Journal of the Structural Division. 1980 Oct; 106(10): $2017-2033$.

10. Dai H, Wang W. Application of low-discrepancy sampling method in structural reliability analysis. Structural Safety 2009; 31(1): 55-64, https://doi.org/10.1016/j.strusafe.2008.03.001.

11. Darmawan M S. Pitting corrosion model for reinforced concrete structures in a chloride environment. Magazine of Concrete Research 2010; 62(2): 91-101, https://doi.org/10.1680/macr.2008.62.2.91

12. Dimitri V V. Deterioration of strength of RC beams due to corrosion and it's influence on beam reliability, Journal of Structural Engineering 2007; 133: 15-42.

13. Ellingwood B. Development of a probability based load criterion for American National Standard A58: Building code requirements for minimum design loads in buildings and other structures. US Department of Commerce, National Bureau of Standards; 1980, https://doi. org/10.6028/nbs.sp.577.

14. Enright M E, Frangopol, D M. Probabilistic analysis of resistance degradation of reinforced concrete bridge beams under corrosion. Engineering Structures Journal 1998; 20(11): 960-971, https://doi.org/10.1016/S0141-0296(97)00190-9.

15. Frangopol D M, Lin K-Y, Estes A C. Reliability of reinforced concrete girders under corrosion attack. Journal of Structural Engineering 1997; 123(3): 286-297, https://doi.org/10.1061/(ASCE)0733-9445(1997)123:3(286).

16. Ghanooni-Bagha M, Shayanfar M A, Shirzadi-Javid A A, Ziaadiny H. Corrosion-induced reduction in compressive strength of selfcompacting concretes containing mineral admixtures. Construction and Building Materials 2016; 113: 221-228, https://doi.org/10.1016/j. conbuildmat.2016.03.046.

17. Gonzales J A, Andrade C, Alonso C, Feliu S. Comparison of rates of general corrosion and maximum pitting penetration on concrete embedded steel reinforcement. Cement and. Concrete Research 1995; 25(2): 257-264, https://doi.org/10.1016/0008-8846(95)00006-2.

18. Li C Q. Reliability based service life prediction of corrosion affected concrete structures. Journal of Structural Engineering 2004; 130(10): 1570-1577, https://doi.org/10.1061/(ASCE)0733-9445(2004)130:10(1570).

19. Li CQ, Zheng J J, Lawanwisut W, Melchers R E. Concrete delamination caused by steel reinforcement corrosion. Journal of Materials in Civil Engineering 2007; 19(7): 591-600, https://doi.org/10.1061/(ASCE)0899-1561(2007)19:7(591).

20. Mirza S A, MacGregor J G. Variability of mechanical properties of reinforcing bars. Journal of the Structural Division $1979 ; 105$ (ASCE 14590 Proceeding): 921-937.

21. Naess A, Leira BJ, Batsevych O. System reliability analysis by enhanced Monte Carlo simulation. Structural Safety 2009; 31(5): 349-355, https://doi.org/10.1016/j.strusafe.2009.02.004.

22. Nogueira C G, Leonel E D. Probabilistic models applied to safety assessment of reinforced concrete structures subjected to chloride ingress. Engineering Failure Analysis 2013; 31: 76-89, https://doi.org/10.1016/j.engfailanal.2013.01.023.

23. Nowak A S, Collins K R. Reliability of structures. CRC Press; 2012.

24. Nowak A S, Szerszen M M, Szeliga E K, Szwed A, Podhorecki P J. Reliability-based calibration for structural concrete. University of Nebraska, UNLCE. 2005:05-3.

25. Östlund L. An estimation of $\gamma$-values. Bulletin du Comité Euro-international du Béton 1991(202): 38-97.

26. Papadakis V G, Roumeliotis A P, Fardis M N, Vagenas C G. Mathematical modelling of chloride effect on concrete durability and protection measures. Concrete repair, rehabilitation and protection 1996; 165-174. 
27. Pedeferri P. La corrosionenelcalcestruzzo: fenomenologia, prevenzione, diagnosi, rimedi, AICAP, progetto Ulisse, Pubblicemento 2005.

28. Shayanfar M A, Barkhordari M A, Ghanooni-Bagha M. Estimation of Corrosion Occurrence in RC Structure Using Reliability Based PSO Optimization. Periodica Polytechnica. Civil Engineering 2015; 59(4): 531-543, https://doi.org/10.3311/PPci.7588.

29. Shayanfar MA, Barkhordari MA, Ghanooni-Bagha M. Probability calculation of rebars corrosion in reinforced concrete using css algorithms. Journal of Central South University 2015; 22(8): 3141-3150, https://doi.org/10.1007/s11771-015-2851-9.

30. Shayanfar M A, Ghanooni-Bagha M, Jahani E. Reliability theorey of structure. Iust publication Tehran, Iran 2016.

31. Simioni P. Seismic response of reinforced concrete structures affected by reinforcement corrosion (Doctoral dissertation, University of Florence) 2009.

32. Stewart M G, Al-Harthy A. Pitting corrosion and structural reliability of corroding RC structures, experimental data and probabilistic analysis. Reliability Engineering and System Safety 2008; 93(3), 373-382, https://doi.org/10.1016/j.ress.2006.12.013.

33. Stewart M G. Mechanical behaviour of pitting corrosion of flexural and shear reinforcement and its effect on structural reliability of corroding RC beams. Structural Safety 2009; 31(1): 19-30, https://doi.org/10.1016/j.strusafe.2007.12.001.

34. Stewart M G. Spatial variability of pitting corrosion and its influence on structural fragility and reliability of RC beams in flexure. Structural Safety 2004; 26(4); 453-470, https://doi.org/10.1016/j.strusafe.2004.03.002.

35. Stewart M G, Suo Q. Extent of spatially variable corrosion damage as an indicator of strength and time-dependent reliability of RC beams. Engineering Structures 2009; 31(1): 198-207, https://doi.org/10.1016/j.engstruct.2008.08.011.

36. Turnbull A. Review of modelling of pit propagation kinetics. British Corrosion Journal. 2013 Jul 18.

37. Tuutti K. Corrosion of steel in concrete. 1982.

38. Val D V, Melchers R E. Reliability of deteriorating RC slab bridges. Journal of structural engineering 1997; 123(12): 1638-1644, https://doi. org/10.1061/(ASCE)0733-9445(1997)123:12(1638).

39. Vu K A, Stewart M G. Structural reliability of concrete bridges including improved chloride-induced corrosion models. Structural Safety 2000; 22(4): 313-333, https://doi.org/10.1016/S0167-4730(00)00018-7.

40. Vu K, Stewart M G, Mullard J. Corrosion-induced cracking: experimental data and predictive models. ACI Structural Journal 2005; 102(5): 719-726.

41. Zhang X, Wang J, Zhao Y, Tang L, Xing F. Time-dependent probability assessment for chloride induced corrosion of RC structures using the third-moment method. Construction and Building Materials 2015; 76: 232-244, https://doi.org/10.1016/j.conbuildmat.2014.10.039.

\author{
Mohammad GHANOONI-BAGHA \\ Department of civil Engineering, East Tehran Branch \\ Islamic Azad University \\ Tehran, Iran
}

Mohsen Ali SHAYANFAR

The Centre of Excellence for Fundamental Studies in Structural Engineering Iran University of Science and Technology

P.O.BOX: 16765-163; Narmak, Tehran, Iran

Omid REZA-ZADEH

School of Civil Engineering

Iran University of Science and Technology

P.O. Box 16765-163, Narmak, Tehran, Iran

\title{
Masoud ZABIHI-SAMANI
}

Department of civil Engineering, Parand Branch

Islamic Azad University

Parand, Iran

Emails: ghanoonibagha@iauet.ac.ir, shayanfar@iust.ac.ir, rezazadeh.omid@yahoo.com,zabihi@piau.ac.ir; 